\title{
Concentration of Total Mercury in Convenience Fish Products and Cooked Fish
}

\author{
Nikolai A. Panichev* (D) ${ }^{\S}$ and Svetlana E. Panicheva \\ Department of Chemistry, Tshwane University of Technology, P.O. Box 56208, Arcadia 0007, Pretoria, South Africa. \\ Received 24 May 2018, revised 7 June 2019, accepted 14 June 2019.
}

\begin{abstract}
Convenience fish products are very popular culinary items among South African customers because they do not require any preliminary preparation before cooking. To the best of our knowledge, convenience fish products had never been a subject of analysis for mercury $(\mathrm{Hg})$ content in South Africa. A Zeeman Mercury Analyzer was used for direct determination of $\mathrm{Hg}$ in these products after thermal decomposition of samples followed by atomic absorption detection. The Hg concentrations in convenience fish products, namely 'Hake crumbed AA portions' and 'Hake AA portions' was found to be at a very low level (8.2 \pm $\left.1.1 \mathrm{ng} \mathrm{g}^{-1}\right)$, and in the other convenience fish products 'Fish bites' and 'Battered mince portions' it was in the range of 48-64 $\mathrm{ng} \mathrm{g}^{-1}$. In 'ready to eat' deep-fried fish, the concentrations of $\mathrm{Hg}$ varied in a much wider range (from 55 to $306 \mathrm{ng} \mathrm{g}^{-1}$ ). To estimate the health risk associated with $\mathrm{Hg}$ in these products, the safe amount of cooked in-store fish and convenience fish products have been calculated.
\end{abstract}

KEYWORDS

Convenience fish products, cooked fish, total mercury, mercury analyzer.

\section{Introduction}

Convenience foods are commercially produced and easy to cook products without time-consuming preparation. This has led to a demand for convenience seafood products in 'ready to eat' and 'ready to cook' forms. Several factors have influenced this demand. One of them is the healthy eating habits of population, resulting in the increasing request for convenience products based on fish; the other is a trend of eating away from home. This has triggered the growth of fast food trade based on fish products. The benefits of consuming fish, as a healthy food are well known, ${ }^{1}$ but information that fish can contain harmful for human health $\mathrm{Hg}$ concentrations, and that mercury can accumulate, is less known. ${ }^{2}$ The organic form of mercury - methylmercury (MeHg), the main chemical form of $\mathrm{Hg}$ present in fish is the most dangerous because $\mathrm{MeHg}$ is a neurotoxin that has a very high ability for bioaccumulation in humans. ${ }^{3}$ As a result, fish is the primary source of human exposure to mercury. The risk associated with mercury through fish consumption depends on many factors, such as fish species, age and the amount of fish consumed..$^{4-5}$ To protect the population from hazardous exposure to $\mathrm{Hg}$ through fish consumption, national and international agencies have set limits for $\mathrm{Hg}$ concentrations in fish. The US Food and Drug Administration set a level of $0.5 \mu \mathrm{g} \mathrm{g}^{-1}$ of $\mathrm{MeHg}$ in herbivorous fish and $1.0 \mu \mathrm{g} \mathrm{g}^{-1}$ for predatory fish (wet weight). ${ }^{6}$ For a vulnerable group of the population that included pregnant and breast-feeding women and the population that uses fish as subsistence, it was recommended to utilize fish with a concentration of $\mathrm{Hg}$ not exceeding $0.3 \mu \mathrm{g} \mathrm{g}^{-1}$ (wet weight)..$^{7-8}$

Consumers of 'ready to eat' cooked fish should be better informed about quality of products they purchase. Mercury content in fish is the most important factor to assess. Recommendation on the amount of fish for safe consumption without adverse effects can be given on the basis of international standards. ${ }^{1,9}$ The Provisional Tolerance Weekly Intake (PTWI) for MeHg set a

* To whom correspondence should be addressed. E-mail: panichevn@ tut.ac.za value of $0.7 \mu \mathrm{g} \mathrm{kg}^{-1}$ of body weight week ${ }^{-1}$ as a safe level of $\mathrm{Hg}$ by the consumption of fish. ${ }^{10}$ From scientific literature, it is known that sea fish contains more than $90 \%$ up to $100 \%$ of total $\mathrm{Hg}$ as methylmercury. ${ }^{7,11}$ Estimation of safe amount of fish consumption can be made according to this norm (PTWI), using results of total mercury measurements. ${ }^{12}$

For the weight of a human body of $60 \mathrm{~kg}$, the weekly consumption of $\mathrm{Hg}$ should not exceed $0.7 \mu \mathrm{g} \mathrm{kg}^{-1} \times 60 \mathrm{~kg}=42 \mu \mathrm{g}$. When the total $\mathrm{Hg}$ concentration in a fish is measured, it is possible to calculate the allowable fish weight for consumption per week through the expression: $\mathrm{P}_{\text {fish }}=42 \mu \mathrm{g} / \mathrm{C}_{\mathrm{Hg}}$ where $\mathrm{P}_{\text {fish }}$ is weight of fish, $\mathrm{g}$, and $\mathrm{C}_{\mathrm{Hg}}$ is concentration of $\mathrm{Hg}$ in a fish, $\mu \mathrm{g} \mathrm{g}^{-1}$. The aim of this study was to analyze samples of convenience fish products and cooked in a store for total $\mathrm{Hg}$ concentration and to calculate the safe amount of convenience fish products and cooked 'ready to eat' fish.

\section{Experimental}

\subsection{Instrumentation and Measurements}

A Model RA-915+ Zeeman Mercury analyzer (Lumex, St. Petersburg, Russia) with a PYRO-915 attachment was used for $\mathrm{Hg}$ measurements. This is a mercury analyzer for the determination of total mercury in solid samples using the method of thermal decomposition of samples and atomic absorption detection, described in EPA Method $74735 .^{13}$ The Mercury analyzer was used previously for analysis of soils, sediments, oil products, foodstuff, etc., for $\mathrm{Hg}$ content. ${ }^{14-16}$ The concentration of $\mathrm{Hg}$ in a sample is determined from a calibration graph, plotted as integrated analytical signal (arbitrary units) vs. absolute mass of $\mathrm{Hg}$ (ng). Real-time measurement of $\mathrm{Hg}$ released from a sample is accomplished with a response time of $1 \mathrm{~s}$ and visualization of the release process on a computer display. Analysis of fish and convenient fish products could be achieved without any chemical pre-treatment. The positive aspect of application of such a mercury analyzer is the use of a thermal decomposition method 
for releasing $\mathrm{Hg}$ from analyzed samples instead of their chemical decomposition. Therefore, elimination of wet chemistry greatly reduces chemical waste, prevents $\mathrm{Hg}$ losses and sample contamination. The performance of the RA-915+ Zeeman mercury analyzer was evaluated using analytical figures of merit, which includes accuracy, linearity, and limit of detection (LOD).

\subsection{Samples}

Samples used in this research were the following convenience fish products and fish:

- Hake crumbed AA portions;

- Hake AA portions;

- Battered mince portions;

- Fish bites;

- Hake fillet;

- Snoek cured;

- Yellowtail fish.

All convenience fish products were bought crumbed or battered and partly cooked in a frozen state. Because the main source of $\mathrm{Hg}$ in convenience fish products is a fish itself, breadcrumbs, batter and fish flesh were analyzed separately. According to suppliers, convenience fish products were commercially prepared from hake and/or pollock and/or blue whiting and/or pangasius and/or hoki without other specification what kind of fish was inside. Therefore, the trade name may be conditional one, and a product content be uncertain. Four fish species are sea fish, with exception of pangasius which is a freshwater fish. Fish flesh, approximately $2 \mathrm{~g}$, was cut out from inside of any product and kept in a zipped plastic bag in a refrigerator before analysis. This sample amount is sufficient for several replicates of analysis. Excess of water, if any present after sample defreezing, was removed by filter paper before weighing.

Deep-fried snoek, cooked in a store from cured snoek and deep-fried battered hake filet were in a 'ready to eat state'. Samples from cooked fish were cut from a soft part of a fish near dorsal fin without batter or skin. Individual plastic zipped bags were also used for cooked fish samples. Samples of yellowtail were analyzed using fresh whole fish samples cut near dorsal fin without skin. The instrument used for sampling procedure was stainless steel knife cleaned and rinsed by deionized water. Samples of fish products were bought at random in different South African stores.

\subsection{The Analytical Performance of the Mercury Analyzer}

For the analysis of convenience fish products and fish itself, it was necessary to take an exact amount of a sample and place it into a sampling quartz boat of Mercury Analyzer. Samples were weighed on analytical balance in the range of $250-300 \mathrm{mg}$. The exact weight of the sample was set into the software of Mercury Analyzer RA- $915^{+}$. When the sampling boat was inserted into an evaporation tube of the instrument, heated to $420^{\circ} \mathrm{C}, \mathrm{Hg}$ vapour were transported by air stream into an analytical cell, heated to $800{ }^{\circ} \mathrm{C}$ for the measurement of $\mathrm{Hg}$ by atomic absorption spectrometry. Background absorption was eliminated by the high-frequency Zeeman correction system. In the process of analysis, the software of Mercury Analyzer $915^{+}$displays a curve of $\mathrm{Hg}$ evaporation and at the end of measurements the area of the peak and calculated $\mathrm{Hg}$ concentration in the sample. Time taken for the analysis of one sample with three replicates is about $10 \mathrm{~min}$.

\subsection{Calibration of the Mercury Analyzer}

The calibration of Mercury Analyzer was performed with standard and certified reference materials, which cover the whole range of possible $\mathrm{Hg}$ concentrations in analyzed samples. The standards include: SRM 1515, Apple leaves, (National institute of Standards and Technology, US Department of Commerce), $\mathrm{Hg}$ concentration of $44 \pm 4 \mathrm{ng} \mathrm{g}^{-1}$; SARM 20, South African coal with certified $\mathrm{Hg}$ concentration $250 \pm 13 \mathrm{ng} \mathrm{g}^{-1}$ and CRM MESS-3, Marine sediment (National Research Council of Canada) with certified value of $\mathrm{Hg}$ concentration $90 \pm 6 \mathrm{ng} \mathrm{g}^{-1}$. The result of calibration shows that under similar operating conditions, standards with different matrices generate signals with absorbance values strictly proportional to absolute amount of $\mathrm{Hg}$. This is confirmed by the straight-line calibration graph, (Fig. 1), obtained after analysis of different standards. Our results confirm that calibration of mercury analyzer, based on thermo evaporation of $\mathrm{Hg}$, can be performed with CRMs of different origins, as demonstrated by Perkin Elmer's method for fish analysis. ${ }^{17}$ The absolute mass of mercury (ng) was calculated from the relationship between the certified value of the $\mathrm{Hg}$ concentration $\left(\mathrm{C}_{\mathrm{Hg}}\right)$ and CRMs mass $\left(\mathrm{m}_{\mathrm{CRM}}, \mathrm{mg}\right)$ taken for the analysis:

$$
\mathrm{m}_{\mathrm{Hg}}(\mathrm{ng})=\mathrm{m}_{\mathrm{CRM}}(\mathrm{mg}) \times \mathrm{C}_{\mathrm{Hg}}\left(\mathrm{ng} \mathrm{mg}^{-1}\right)
$$

The calibration curve is described by the equation: $y=350.62 x$ -71.58 .

Excellent linearity $\left(\mathrm{R}^{2}=0.9993\right)$ up to $90 \mathrm{ng}$ of $\mathrm{Hg}$ was achieved. This absolute amount of $\mathrm{Hg}$ is equivalent to relative $\mathrm{Hg}$ concentration of $360 \mathrm{ng} \mathrm{g}^{-1}$ in fish for a mean sample mass of $250 \mathrm{mg}$.

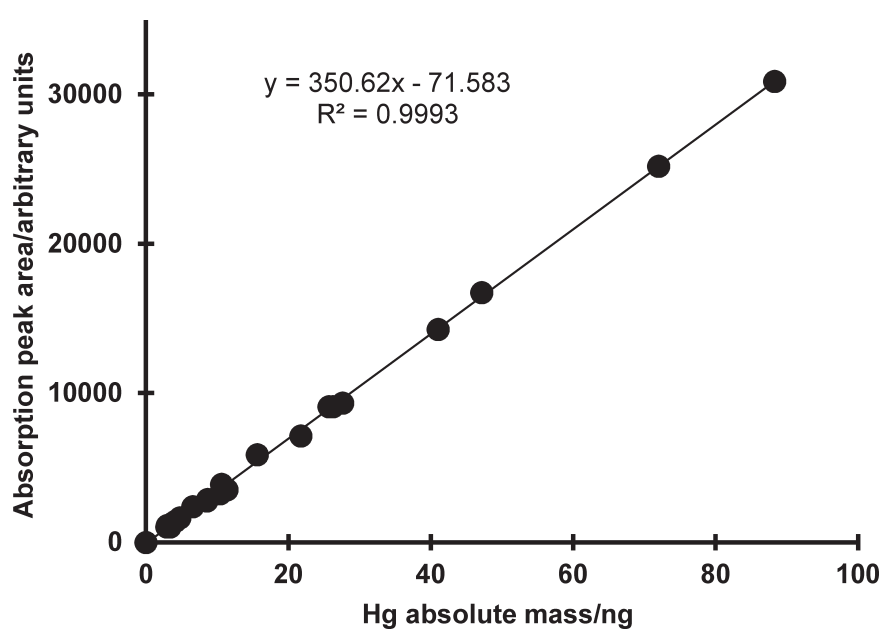

Figure 1 Calibration curve for $\mathrm{Hg}$ determination.

\subsection{Limit of Detection}

Due to the absence of fish or fish products that could be used as blanks, calculation of the LOD was derived from the calibration curve, presented in a general form $y=b x+a$. Numerical calculations were performed with Microsoft Excel statistics, using the equation: $\mathrm{LOD}=(\mathrm{a}+3 \mathrm{Sa}) / \mathrm{b}$, where $\mathrm{Sa}$ is the standard deviation of the response $y$ and $b$ is the slope of the calibration curve. ${ }^{18}$ By regression analysis of the graphical equation, the absolute LOD was found to be $0.32 \mathrm{ng}$. With a mean sample mass of $250 \mathrm{mg}$, the relative LOD is $1.3 \mathrm{ng} \mathrm{g}^{-1}$. This value is below the lowest concentrations of $\mathrm{Hg}$ ( 2.6 and $\left.8.1 \mathrm{ng} \mathrm{g}^{-1}\right)$ found in the convenience fish products.

\subsection{Validation of Results}

The accuracy of the measurements was confirmed by the analysis of CRM TORT-2, Lobster hepatopancreas (NRC Canada, Canada) with good correspondence of certified $292 \pm 22 \mathrm{ng} \mathrm{g}^{-1}$ and found values $283 \pm 25 \mathrm{ng} \mathrm{g}^{-1}, \mathrm{n}=6$. 
The SRM 1515, Apple leaves with certified value $44 \pm 4 \mathrm{ng} \mathrm{g}^{-1}$ was used to control the stability of calibration curve position in time. Analyses of this SRM at the beginning and at the end of each set of samples verified that the instrument calibration remained stable. The mean value of $\mathrm{Hg}$ concentration in SRM 1515 , Apple leaves was found to be $45 \pm 6 \mathrm{ng} \mathrm{g}^{-1}(\mathrm{n}=35)$.

\section{Results and Discussion}

\subsection{Results of $\mathrm{Hg}$ Determination in Convenience Fish \\ Products and Fish}

The results of $\mathrm{Hg}$ determination in wet samples, of 'ready to cook' convenience fish products and 'ready to eat' deep-fried fish cooked in a store, are presented in Table 1 . There are data on mean concentration of $\mathrm{Hg}$ (Mean $[\mathrm{Hg}]$ ) in fish products, and maximum safe amount for consumption by a person with a body weight of $60 \mathrm{~kg}$. Both 'Hake crumbed AA portions' and 'Hake AA portions' were found to have very low, practically uniform $\mathrm{Hg}$ concentrations of 8.1 and $8.2 \mathrm{ng} \mathrm{g}^{-1}$. The trade name of these two commercial products is arbitrary.

The other kind of convenience fish products 'Fish bites' and 'Battered mince portions' also have relatively low $\mathrm{Hg}$ concentration, in the range $48-64 \mathrm{ng} \mathrm{g}^{-1}, \mathrm{n}=13$. The $\mathrm{Hg}$ concentrations fit tightly inside of these product categories. For convenience fish products, the value of relative standard deviation (RSD \%) of $\mathrm{Hg}$ determination was found to be in the range 4.2-13.6\%. Concentrations of $\mathrm{Hg}$ in 'breadcrumbs' and 'batter' samples were found to be at a 'trace' level of $2.6 \pm 0.33 \mathrm{ng} \mathrm{g}^{-1}, \mathrm{n}=3$.

Limit of detection of $\mathrm{Hg}$ determination, equal to the value of three standard deviations of $\mathrm{Hg}$ concentrations in 'breadcrumbs'

Table $1 \mathrm{Hg}$ content in convenience fish products, 'ready to eat' fish, and calculated safe amounts of weekly consumption for a person of $60 \mathrm{~kg}$ of body weight.

\begin{tabular}{|c|c|c|c|c|c|}
\hline $\begin{array}{l}\text { Sample } \\
\text { no. }\end{array}$ & $\begin{array}{l}\text { Name of a product and } \\
\text { its state at purchase }\end{array}$ & $\begin{array}{l}\text { Mean }[\mathrm{Hg}] \text { in } \\
\text { samples } \\
\mathrm{C} \pm \mathrm{SD} \\
/ \mathrm{ng} \mathrm{g}^{-1}, \mathrm{n}=3\end{array}$ & $\begin{array}{l}\text { Mean }[\mathrm{Hg}] \text { in } \\
\text { products } \\
\mathrm{C} \pm \mathrm{SD} \\
/ \mathrm{ng} \mathrm{g}^{-1}\end{array}$ & $\begin{array}{l}\text { Maximum safe } \\
\text { amount for } \\
\text { consumption } \\
/ \mathrm{kg}\end{array}$ & Comment \\
\hline $\begin{array}{l}1 \\
2 \\
3 \\
4 \\
5\end{array}$ & $\begin{array}{l}\text { *Hake crumbed AA portions, } \\
\text { frozen, wet. }\end{array}$ & $\begin{array}{l}8.6 \pm 0.53 \\
7.5 \pm 1.10 \\
9.1 \pm 0.55 \\
6.1 \pm 0.17 \\
9.3 \pm 0.20\end{array}$ & $8.1 \pm 1.0$ & 5.185 & Partly cooked as sold. \\
\hline $\begin{array}{l}6 \\
7 \\
8 \\
9 \\
10 \\
11 \\
12 \\
13\end{array}$ & $\begin{array}{l}{ }^{*} \text { Hake AA portions, } \\
\text { frozen, wet }\end{array}$ & $\begin{array}{c}6.9 \pm 1.3 \\
5.7 \pm 0.53 \\
6.9 \pm 1.4 \\
12.3 \pm 2.3 \\
12.6 \pm 1.5 \\
7.4 \pm 1.2 \\
4.7 \pm 0.40 \\
9.5 \pm 0.58\end{array}$ & $8.2 \pm 1.3$ & 5.122 & Partly cooked as sold. \\
\hline $\begin{array}{l}14 \\
15 \\
16 \\
17 \\
\end{array}$ & $\begin{array}{l}\text { Battered mince portions, } \\
\text { frozen, wet }\end{array}$ & $\begin{array}{l}44.7 \pm 3.1 \\
45.0 \pm 5.0 \\
37.7 \pm 1.5 \\
65.0 \pm 1.0\end{array}$ & $48.1 \pm 3.1$ & 0.873 & Partly cooked as sold. \\
\hline $\begin{array}{l}18 \\
19 \\
20\end{array}$ & $\begin{array}{l}\text { Fish bites, } \\
\text { frozen, wet }\end{array}$ & $\begin{array}{l}52.0 \pm 1.7 \\
51.7 \pm 3.1 \\
48.7 \pm 3.5\end{array}$ & $50.8 \pm 2.9$ & 0.827 & $\begin{array}{l}\text { Additionally cooked on a pan with } \\
\text { sunflower oil. }\end{array}$ \\
\hline $\begin{array}{l}21 \\
22 \\
23 \\
24 \\
25 \\
26\end{array}$ & $\begin{array}{l}\text { Fish bites, } \\
\text { frozen, wet }\end{array}$ & $\begin{array}{l}65.3 \pm 4.5 \\
60.0 \pm 3.0 \\
76.7 \pm 2.9 \\
57.0 \pm 1.0 \\
72.0 \pm 2.0 \\
56.3 \pm 1.5\end{array}$ & $64.6 \pm 2.7$ & 0.650 & Partly cooked as sold. \\
\hline $\begin{array}{l}27 \\
28 \\
29\end{array}$ & Breadcrumbs and batter & $\begin{array}{l}1.5 \pm 0.05 \\
4.0 \pm 0.1 \\
2.2 \pm 0.3\end{array}$ & $2.6 \pm 0.33$ & & $\begin{array}{l}\text { Breadcrumbs and batter from fish } \\
\text { products. }\end{array}$ \\
\hline $\begin{array}{l}30 \\
31 \\
32 \\
33\end{array}$ & $\begin{array}{l}\text { Deep-fried snoek samples, } \\
\text { wet }\end{array}$ & $\begin{array}{l}219 \pm 19 \\
138 \pm 9.2 \\
306 \pm 1.9 \\
168 \pm 3.4\end{array}$ & - & $\begin{array}{l}0.192 \\
0.304 \\
0.137 \\
0.250\end{array}$ & $\begin{array}{l}\text { Deep-fried in a vegetable oil, ready } \\
\text { to eat. }\end{array}$ \\
\hline $\begin{array}{l}34 \\
35 \\
36 \\
37\end{array}$ & $\begin{array}{l}\text { Deep fried battered hake } \\
\text { fillet samples, } \\
\text { wet }\end{array}$ & $\begin{array}{l}74 \pm 12 \\
93 \pm 1.2 \\
83 \pm 1.1 \\
55 \pm 0.6\end{array}$ & - & $\begin{array}{l}0.568 \\
0.452 \\
0.506 \\
0.764\end{array}$ & $\begin{array}{l}\text { Deep-fried in a vegetable oil, ready } \\
\text { to eat. }\end{array}$ \\
\hline
\end{tabular}

*Information provided by a supplier: fish used for the convenience products are: 'Hake and/or Pollock and/or Blue Whiting and/or Pangasius and/or Hoki'. The products also contain breadcrumbs, butter and cottonseed oil. 
and 'batter', as samples with the lowest $\mathrm{Hg}$ concentrations were found to be approximately $1.0 \mathrm{ng} \mathrm{g}^{-1}$. The other value of LOD estimated from the results of $\mathrm{Hg}$ determination in convenience fish products with a concentration of $4.7 \pm 0.40 \mathrm{ng} \mathrm{g}^{-1}$ (sample 12, Table 1) was found to be $1.2 \mathrm{ng} \mathrm{g}^{-1}$. These two values of LOD are close to the value of $1.3 \mathrm{ng} \mathrm{g}^{-1}$ estimated LOD through the regression line. Concentrations of $\mathrm{Hg}$ in 'ready to eat' deep-fried snoek (range 168-306 $\mathrm{ng} \mathrm{g}^{-1}, \mathrm{n}=4$ ) and hake fillet samples (range $55-93 \mathrm{ng} \mathrm{g}^{-1}, \mathrm{n}=4$ ) correspond to moderate $\mathrm{Hg}$ concentrations in fresh species of snoek and hake. ${ }^{5,16}$ Relative standard deviation of this analysis was in the range 1.0-16\%.

The evaluation of recommended amount of convenience fish product that may be consumed without health risk, was performed on the norm of Provisional Tolerance Weekly Intake (PTWI) $0.7 \mu \mathrm{g} \mathrm{kg}^{-1}$ body weight week ${ }^{-1}$ (USA FDA) for a person of $60 \mathrm{~kg}$ weight. The calculated data show that while some of commercially produced convenience fish products can be consumed practically without limitation (the first 13 samples in Table 1), the consumption of deep-fried snoek should be limited to one deep-fried hake, to three 125-150 g portions per week. The consumption of 'Fish bites' and 'Battered mince' portions should be limited to four and six 125-150 g portions per week, with orientation on the highest $\mathrm{Hg}$ concentration in products. For a person with body weight other than $60 \mathrm{~kg}$, the safe amount for consumption (Table 1) could be increased or reduced by ratio of actual body weight to accepted $60 \mathrm{~kg}$. Comparing results of 'ready to cook' or partly cooked commercially produced fish products and 'ready to eat' fish, cooked in a store, it is easy to notice that 'ready to cook' products contain smaller concentrations of $\mathrm{Hg}$ and therefore have a lower health risk.

It would be practical for a store to cook some other species of fish with lower levels of $\mathrm{Hg}$ which corresponds to US FDA data. ${ }^{11}$ A local fish, which corresponds to this requirement, is yellowtail fish. The mean concentration of $\mathrm{Hg}$ in fresh yellowtail fish was found to be $55.7 \pm 3.8 \mathrm{ng} \mathrm{g}^{-1}(\mathrm{n}=37)$ for a whole fish with weights from 0.6 to $2.8 \mathrm{~kg}$, relative standard deviation was $6.8 \%$. The other advantage of this fish is the experimentally confirmed fact that $\mathrm{Hg}$ content in yellowtail fish could be reduced by cooking in boiling sunflower oil by $19 \%$ and by preparation over burning coal up to $26 \%$. $^{19}$

\section{Conclusion}

- It was found that convenience fish products and 'ready to eat' fish sold in South African retail stores contain $\mathrm{Hg}$ in concentrations below guidelines of $500 \mathrm{ng} \mathrm{g}^{-1}$;

- The result of $\mathrm{Hg}$ determination in 'Hake crumbed AA portions' and 'Hake AA portions' shows that these convenience fish products have very low and similar $\mathrm{Hg}$ concentrations of $8.1 \pm$ $1.0 \mathrm{ng} \mathrm{g}^{-1}$ and $8.2 \pm 1.3 \mathrm{ng} \mathrm{g}^{-1}$. They can be consumed in any reasonable amount;

- The other convenience fish products 'Fish bites' and 'Battered mince portions' have low $\mathrm{Hg}$ concentrations in the range $48-64 \mathrm{ng} \mathrm{g}^{-1}$; allowable number of $125-150 \mathrm{~g}$ portions is $4-6$ per week;

- The concentrations of mercury in 'ready to eat' fish, cooked in a store, varies from $55 \pm 0.6 \mathrm{ng} \mathrm{g}^{-1}$ to relatively high concentrations of $306 \pm 2 \mathrm{ng} \mathrm{g}^{-1}$;

- As a measure of precaution, the consumption of deep-fried snoek should be limited to one and deep-fried hake to three 125-150 g portions per week;

- It is recommended to add yellowtail fish to the list of 'ready to eat' fish cooked in a store, because it has low $\mathrm{Hg}$ concentrations of $55.7 \pm 3.8 \mathrm{ng} \mathrm{g}^{-1}$ that can be reduced by cooking by approximately $20 \% .^{19}$

\section{Acknowledgements}

The authors are grateful to the National Research Foundation of South Africa for financial support of this work, Grant Number 81298.

\section{${ }^{5}$ ORCID iD}

N.A. Panichev: (D) orcid.org/0000-0003-4269-1447

\section{References}

1 FAO/WHO, 2011, Report on Joint Expert Consultation on the Risks and Benefits of Fish Consumption, FAO Fishery and Aquaculture Report, Rome.

2 WHO, 2017, Mercury and Health Fact Sheet, available at: http://www.who.int/mediacentre/factsheets/fs361/en/ (accessed November 2017)

3 ATSDR (Agency for Toxic Substances \& Disease Registry), 2018, Priority List of Hazardous Substances:

http://www.atsdr.cdc.gov/spl/

4 US EPA, 2001, Methylmercury (MeHg), CASRN 22967-92-6.5

5 US FDA (U.S. Food and Drug Administration), 2012, Mercury Levels in Commercial Fish and Shellfish (1990-2010).

http://www.fda.gov/Food/FoodborneIllnessContaminants/Metals/ ucm115644.htm6

6 FAO/WHO (Food and Agriculture Organization of the United Nations/ World Health Organization), Safety Evaluation of Certain Food Additives and Contaminants. Methylmercury, WHO Food Additives Series, 2004, $52,565-623$.

7 EFSA, Scientific opinion on the risk for public health related to the presence of mercury and methylmercury in food, EFSA Journal, 2012, 10, 2985.

8 USA FDA, 2017, Eating Fish: What Pregnant Women and Parents Should Know?

http://www.fda.gov/Food/ResourcesForYou/Consumers/ucm3930 70.htm

9 UNEP/WHO, 2008, Guidance for Identifying Populations at Risk from Mercury Exposure, Issued by UNEP DTIE Chemical Branch and WHO Department of Food Safety, Zoonoses and Foodborne Diseases, Geneva, Switzerland.

10 US-EPA (United States Environmental Protection Agency), 1997, Mercury Study Report to Congress EPA-452/R-97-004, Volume 5, Health Effects of Mercury and Mercury Compounds, United States Environmental Protection Agency, Washington, DC. Available at: http://www.epa.gov/ttn/oarpg/t3/reports/volume5.pdf

11 K. May, M. Stoeppler, K. Reisinger, Studies in the ratio total mercury/methylmercury in the aquatic food chain, Toxicol. Environ. Chem., 1987, 13, 153-159.12

12 L-C. Chien, C-Y. Yeh, C-B. Jiang, C-S. Hsu, B-C. Han, Estimation of acceptable mercury intake from fish in Taiwan, Chemosphere, 2007, 67, 29-35.

13 EPA Method 7473:

http://www.epa.gov/osw/hazard/testmethods/sw846/pdfs/7473.pdf

14 S. Sholopov, S. Pogarev, V. Ryzhov, N. Mashyanov and A. Stroganov, Zeeman atomic absorption spectrometer RA $915^{+}$for direct determination of mercury in air and complex matrix samples, Fuel Process Technol., 2004, 84, 473-485.

15 R.J. Huang, Zh. X. Zhuang, Y.R. Wang, Zh.Y. Huang, X.R. Wang and F.S.C. Lee, An analytical study of bioaccumulation and the binding forms of mercury in rat body using thermolysis coupled with atomic absorption spectrometry, Anal. Chim. Acta, 2005, 538, 313-321.

16 N.A. Panichev and S.E. Panicheva, Determination of total mercury in fish and sea products by direct thermal decomposition atomic absorption spectrometry, Food Chem., 2015, 166, 432-441.

17 The Determination of Total Mercury in Fish and Agricultural Plant Materials Using Thermal Decomposition and Amalgamation Coupled with Atomic Absorption, PerkinElmer, Inc.

18 J.N. Miller and J.N. Miller, Statistics and Chemometrics for Analytical Chemistry, 5th edn, Pearson Education Limited, England, 2005.

19 N.A. Panichev and S.E. Panicheva, Influence of different cooking procedure on the $\mathrm{Hg}$ concentration in fish, Fisheriessciences.com, 2016, 10, 063-069. 